
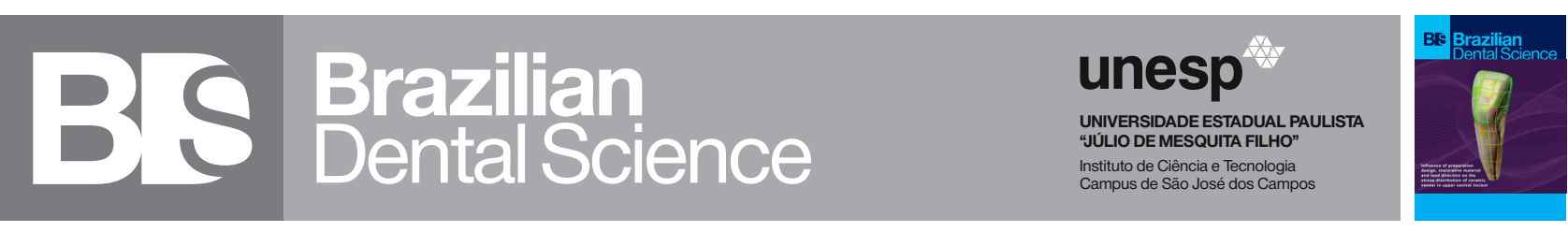

\title{
Analysis of the association of parameters in the formation of ultrafine fibers from PEl and PMMA
}

Análise da associação de parâmetros na formação de fibras ultrafinas de PEl e PMMA

\begin{abstract}
Elisa Camargo KUKULKA ${ }^{1}$, Joyce Rodrigues de SOUZA ${ }^{1}$, Jéssica Dias SANTOS ${ }^{1}$, Tiago Moreira Bastos CAMPOS ${ }^{2}$, Alexandre Luiz Souto BORGES ${ }^{1}$

1 - Institute of Science and Technology of Sao Jose dos Campos, São Paulo State University (UNESP), Sao Jose dos Campos, Brazil.

2 - Technological Institute of Aeronautic (ITA), Sao Jose dos Campos, Brazil.
\end{abstract}

\begin{abstract}
Objective: The aim of the study was to fabricate and morphologically characterizeultrafinePolyetherimide fibers (PEI) associated with Polymethylmethacrylate (PMMA) - PP (group formed by the association of PEI with PMMA), produced by the electrospinning process. Material and Methods: A solution of PEI $(0.562 \mathrm{~g})+$ PMMA $(0.377 \mathrm{~g})$ dissolved in $2.5 \mathrm{~mL}$ of chloroform, $0.85 \mathrm{~mL}$ of Dimethylformamide (DMF) and $0.85 \mathrm{~mL}$ of 1.1.2.2 Tetrachloroethane (TCE) was prepared. For the electrospinning process, different continuous voltages (10 to $18 \mathrm{kV}$ ) and two different distances ( 8 and $12 \mathrm{~cm}$ ) between the needle tip and the collecting apparatus were used, giving rise to 6 distinct groups of ultrafine fibers (PP 1 to 6) that were observed in Scanning Electron Microscopy to check for defects and calculate the average diameter of the fibers. Results: The best parameter, the parameter that was most effective for the production of fibers, observed was subjected to Energy Dispersion X-ray Spectroscopy (EDS), X-ray Diffraction (XRD) and Contact Angle Analysis tests. The data were analyzed using the ANOVA and Tukey test $(\mathrm{p}<0.05)$. From the comparative analysis of the pre-established parameters, the pattern of PP4 ultrafine fibers was shown to be more effective. Conclusion: The PP4 standard $(13 \mathrm{kV}-12 \mathrm{~cm})$ had an average diameter of $0.37 \mu \mathrm{m}$. An adequate parameter to electrospinning was able to produce ultrafine fibers of PMMA/PEI.
\end{abstract}

\section{KEYWORDS}

Polymethylmethacrylate; Scanning electron microscopy; Polyetherimide; Electrospinning process.

\section{RESUMO}

Introdução: O objetivo do estudo foi sintetizar e caracterizar morfologicamente fibras ultrafinas de Polieterimida (PEI) associadas ao Polimetilmetacrilato (PMMA) - PP (grupo formado pela associação de PEI com PMMA), produzidas pelo processo de eletrofiação. Material e Métodos: Foi preparada uma solução de PEI (0,562 g) + PMMA (0,377 g) dissolvido em 2,5 $\mathrm{mL}$ de clorofórmio, $0,85 \mathrm{~mL}$ de Dimetilformamida (DMF) e 0,85 mL de 1.1.2.2 Tetracloroetano (TCE). Para o processo de eletrofiação, foram utilizadas diferentes tensões contínuas (10 a $18 \mathrm{kV})$ e duas distâncias diferentes (8 e $12 \mathrm{~cm}$ ) entre a ponta da agulha e o aparelho coletor, dando origem a 6 grupos distintos de fibras ultrafinas (PP 1 a 6) que foram observados em Microscopia Eletrônica de Varredura para verificar defeitos e calcular o diâmetro médio das fibras. Resultados: O melhor parâmetro, o parâmetro mais eficaz para a produção de fibras, observado foi submetido aos testes de Espectroscopia de Dispersão de Energia (EDS), Difração de Raios X (DRX) e Análise do Ângulo de Contato. Os dados foram analisados pela ANOVA e teste de Tukey ( $p<0,05$ ). A partir da análise comparativa dos parâmetros préestabelecidos, o padrão das fibras ultrafinas PP4 mostrou-se mais eficaz. Conclusão: O padrão PP4 (13 $\mathrm{kV}-12 \mathrm{~cm}$ ) apresentou diâmetro médio de $0,37 \mu \mathrm{m}$. Um parâmetro adequado para eletrofiação foi capaz de produzir fibras ultrafinas de PMMA / PEI.

\section{PALAVRAS-CHAVE}

Polimetilmetacrilato; Microscopia eletrônica de varredura; Polieterimida; Processo de eletrofiação. 


\section{INTRODUCTION}

U ltrafine fibers (fibers with a diameter between micrometers to nanometers) incorporated in composite resins have shown highter efficiency by improving the mechanical properties of the material, increasing strength, elasticity and providing low coefficients of thermal expansion, which make them ideal candidates for many important applications with more satisfactory clinical results than when used without any structural reinforcement [1-5].

Currently, polymeric fibers made on a nanoscale by the electrospinning technique, have been associated with increased strength of resinous materials as a study which incorporated ultrafine fibers of polyvinyl alcohol in polymethylmethacrylate resin [6]. Another polymer studied is polyacrylonitrile, which added in a composite resin in the form of ultrafine fibers increased the material's hardness, in addition to not negatively affecting the bending properties [7]. Similarly, the incorporation of aligned and misaligned Nylon-6 ultrafine fibers in composite resin also contributes to increasing the flexural strength of the material [8].

In this sense, electrospinning gains importance as it is a simple and versatile method for generating ultrafine fibers, using a wide variety of materials such as polymers, composites and ceramics, or a versatile and viable technique for generating ultrathin fibers. Remarkable progress has been made with regard to the development of electrospinning methods and engineering of electrospun nanofibers to suit or enable various applications [9]. This methodology comprises the use of 3 elements: a high voltage source used to generate an electric field, a syringe with a small diameter needle, charged by a positive electrode and the collector, connected to the negative (neutral) electrode. When the potential difference generated exceeds the solution's surface energy, it is elongated and ejected against the collector [9]. In this way, the application of an electrical force over a liquid polymer promotes the ejection of a thin cone-shaped jet, the Taylor cone, which is elongated and accelerated by the electric field and deposited on a substrate in the form of a fiber mat ultrafine [10].

Although electrospinning is a simple method, some parameters can be varied in order to optimize the production of ultrafine fibers, such as: the flow rate with which the solution is ejected, the potential difference generated in the electric field, the distance between the tip of the needle and the collector, and the diameter of the needle. Environmental factors, such as temperature and humidity, can also influence the process $[1,3]$.

Thus, the study of new polymeric materials becomes relevant. Polyetherimide (PEI) is an amorphous thermoplastic polymer with excellent properties that include: high mechanical resistance, thermal and chemical stability. Their properties are compared with metallic and ceramic materials for their elasticity, toughness, impact and abrasion resistance, good insulation and chemical resistance and exposure to time $[11,12]$.

Methyl Polymethacrylate (PMMA) is a synthetic polymeric material from the group of plastics. Since 1940 there have been reports of its use for making dentures in dentistry [13], and since then, the material has been used on a large scale. Among the main characteristics that favor its extensive application, the following stand out: the ease of handling and polishing, the fact of dispensing high-cost equipment, stability in the oral environment and guaranteed aesthetics [14].

The aim of the study was to manufacture and evaluate the influence of the association of the parameters involved in the electrospinning process in the groups of fibers formed (PP1 to PP6) in order to select the best association of the parameters across the group with the best fiber formation.

\section{MATERIALS AND METHODS}

\section{FABRICATE OF ULTRAFINE FIBERS}

Fabricate of the polyetherimide / polymethylmethacrylate solution (PEI / PMMA) 
A solution was prepared containing 0.377 g of PMMA (Degudent / Dentsply, São Paulo, Brazil), $0.562 \mathrm{~g}$ of PEI (Sigma-Aldrich, Saint Louis, EUA) in $0.85 \mathrm{~mL}$ of Dimethylformamide (Sigma-Aldrich, Saint Louis, EUA), $0.85 \mathrm{~mL}$ of Tetrachloroethane (Sigma-Aldrich, Saint Louis, EUA) and $2.5 \mathrm{~mL}$ of Chloroform (LabSynth, São Paulo, Brazil). The solution was placed on a magnetic stirrer (IKA RH Basic, Staufen, Germany) where it remained for 24 hours.

\section{Fabricate of ultrafine fibers by electrospinning}

Then, electrospinning was performed on equipment consisting of a high voltage source $(0-25 \mathrm{kV})$, an injection pump for flow control, a $5 \mathrm{~mL}$ plastic syringe with a straight needle, and a collection device covered with aluminum foil thin $(0.2 \mathrm{~mm})$. The variables used were: voltage, distances from the tip of the needle to the collection device, varying, generating six morphological patterns of ultrafine fibers.

\section{Parameters for the fabricate of ultrafine PEI / PMMA fibers}

For the PEI / PMMA solution, the voltage was varied at 10,13 and $15 \mathrm{kV}$ the distance from the needle to the bulkhead at 8 and $12 \mathrm{~cm}$, with an ejection flow of $2 \mathrm{mLh}^{-1}$ and a needle diameter of $0.7 \mathrm{~mm}$. The generated samples are represented in Table I.

Table I - Representation of the variations in the parameters of the PEI / PMMA ultrafine fiber samples

\begin{tabular}{|c|c|c|c|c|}
\hline Voltage (kV) & & & & \\
\hline \multirow{3}{*}{ Distance (cm) } & & 10 & 13 & 15 \\
\hline & 8 & PP1 & PP3 & PP5 \\
\hline & 12 & PP2 & PP4 & PP6 \\
\hline
\end{tabular}

Ten minutes were standardized for the collection of fibers for each combination of variables. After collecting the fibers, they were stored in a desiccator for forty-eight hours for evaporation of the remaining solvent.

\section{FIBERS}

CHARACTERIZATION OF ULTRAFINE

\section{Scanning electron microscopy}

$0.5 \times 0.5 \mathrm{~cm}$ specimen of the aluminum foil of each morphological pattern generated from the ultrafine fibers were coated with gold (SC7620 Mini Sputer Coater / Glow Discharge System, Emitech, East Sussex, UK) and analyzed by means of Electron Microscopy Scanning (SEM) to evaluate the morphology, alignment, diameter and quantity of the fibers.

Electrospun nanofibers micrographies were obtained using the Scanning Electron Microscope With high-vacuum equipment (Inspect S 50, FEI Company, Brno, Czech Republic) operating at 20$25 \mathrm{KV}, 5.0$ spot and magnifications of 2.000x.

\section{Analysis of the average fiber diameter}

The diameter analysis was performed using the Image $\mathrm{J}$ software (Version 1.4.4, National Public of Health), by which 50 measurements were collected in each image of the generated patterns to obtain the mean diameter in micrometers, standard deviation and coefficient of variation.

\section{(EDS) analysis \\ Energy dispersion X-ray spectroscopy}

To perform a qualitative analysis of the chemical composition of the chemical elements of the NFs (nanofibers), an energy dispersion spectrometer (EDS) (Bruker Nano GmbH 410, Berlin, Germany) associated with the Espirit 1.9 software (Bruker, Berlin, Germany) in the SEM (Inspect S50, FEI Company, Brno, Czech Republic).

\section{X-ray diffraction analysis (XRD)}

The analyzed specimen were prepared in $3 \times 3 \mathrm{~cm}$ format and placed in the XRD device (Shimadzu XRD7000, CuKa radiation, $2 \theta=20$ $80^{\circ}, 30 \mathrm{~mA}, 40 \mathrm{kV}$ ). Institute of Sciences and Technology - UNIFESP, São José dos Campos.

\section{Contact angle analysis}

For the wettability analysis, 3 specimen of the PEI / PMMA fibers were prepared, and then the contact angle of the surfaces was analyzed using an optical tensiometer (TL 1000 - Invoiced freight, Theta Lioe, Attension, Lichfield, Staffordshire, UK), 
where a glass syringe from the system (Gastight Syringes \# 1001 - 1 mL, Hamilton, Reno, Nevada, USA) deposits a drop of distilled water on the specimen surface.

\section{RESULTS}

\section{Scanning electron microscopy}

Through SEM analysis, six micrographs were obtained for the ultrafine PEI/PMMA fibers as shown in Figure 1.

Analysis of the average diameter of the PEI / PMMA ultrafine fibers

The statistics of the mean values of the diameters of the PEI / PMMA fibers ( $\mu \mathrm{m})$ using the ANOVA test 2-way are considered in Table II.

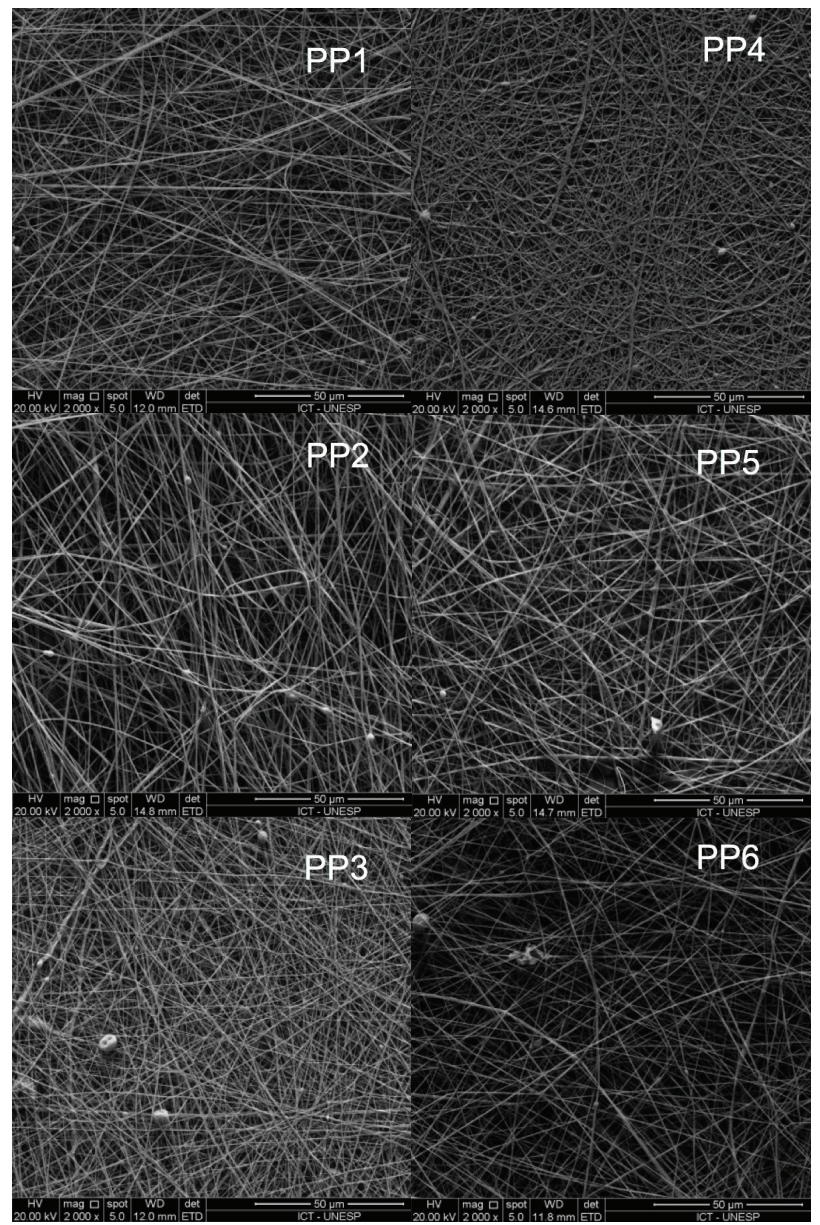

Figure 1 - Micrographs of fabricated PEI / PMMA ultrafine fibers. 2000x increase.
Table II - Analysis of comparison of Tukey factors of ultrafine PEI/PMMA fibers

\begin{tabular}{|c|c|c|c|}
\hline Factor & $\mathbf{N}$ & Mean \pm sd & Grouping \\
\hline PP1 & \multirow{6}{*}{50} & $0,52 \pm 0,21$ & A \\
\hline PP2 & & $0,45 \pm 0,16$ & $A B$ \\
\hline PP5 & & $0,42 \pm 0,14$ & B \\
\hline PP3 & & $0,40 \pm 0,15$ & B \\
\hline PP4 & & $0,37 \pm 0,13$ & B \\
\hline PP6 & & $0,37 \pm 0,13$ & B \\
\hline
\end{tabular}

Through the comparative analysis of the samples, the absence of defects (beads), the smallest diameter of the fibers, the smallest coefficient of variation, the smallest voltage and the shortest distance used for the fabricate of the fibers were analyzed, the PP4 standard was selected. In this, the smallest diameter was found, $0.37 \pm 0.13 \mu \mathrm{m}$, with a coefficient of variation of $0.34 \mu \mathrm{m}$, voltage of $13 \mathrm{kV}$ and distance from the needle to the bulkhead of $12 \mathrm{~cm}$. The ultrafine fibers not described (beads), and are uniform and bulky.

\section{Energy dispersion X-ray spectroscopy}

With the EDS it was possible to verify the presence of the constituent elements of the polymers PEI and PMMA (Carbon, Nitrogen and Oxygen), proving the presence of the polymers in the electrospun fibers. The presence of the chemical elements Aluminum and Gold are attributed to the collection process during electrospinning (Al) and to the preparation of the samples for scanning electron microscopy (Au). The chemical element Hydrogen, one of the compounds of the polymers used was not evidenced by the process due to the size of its molecule. The EDS results can be seen in Table III.

Table III - Table resulting from the EDS test with the percentages of the elements present

\begin{tabular}{ccccccccc}
$\begin{array}{c}\text { ELAN } \\
\text { Series } \\
\text { unn. }\end{array}$ & $\begin{array}{c}\text { Cnorm. } \\
\text { [wt.\%] }\end{array}$ & $\begin{array}{c}\text { CAtom. } \\
\text { [wt.\%] }\end{array}$ & $\begin{array}{c}\text { CError. } \\
\text { [wt.\%] }\end{array}$ & $\begin{array}{c}\text { KFact. } \\
\text { [wt.\%] }\end{array}$ & Zcorr & A corr & F corr. \\
\hline C6 & 56.80 & 54.66 & 74.59 & 6.50 & 1.036 & 0.527 & 1.000 \\
\hline Au79 & 19.62 & 18.88 & 1.57 & 0.61 & 0.128 & 1.304 & 1.000 \\
\hline $\mathbf{0 8}$ & 17.37 & 16.72 & 17.13 & 2.23 & 0.189 & 0.884 & 1.000 \\
\hline Cl17 & 6.87 & 6.61 & 3.06 & 0.26 & 0.020 & 3.269 & 1.000 \\
\hline N7 & 3.25 & 3.13 & 3.66 & 0.67 & 0.034 & 0.919 & 1.000 \\
\hline
\end{tabular}




\section{X-ray diffractometry}

In figure 2 , it is possible to observe the XRD analysis for ultrafine PEI/PMMA fibers, where no sharp diffraction lines were presented, confirming the non-crystalline nature of the polymer. TheXRD analysis is used so that, through the analysis of the diffraction of the material submitted to the test, the resulting diffraction pattern, which comprises both the positions and the intensities of the diffraction effects, serves not only for its rapid identification, but also for the complete elucidation of its structure, thus being able to corroborate the presence in the fibers formed of the polymers used.

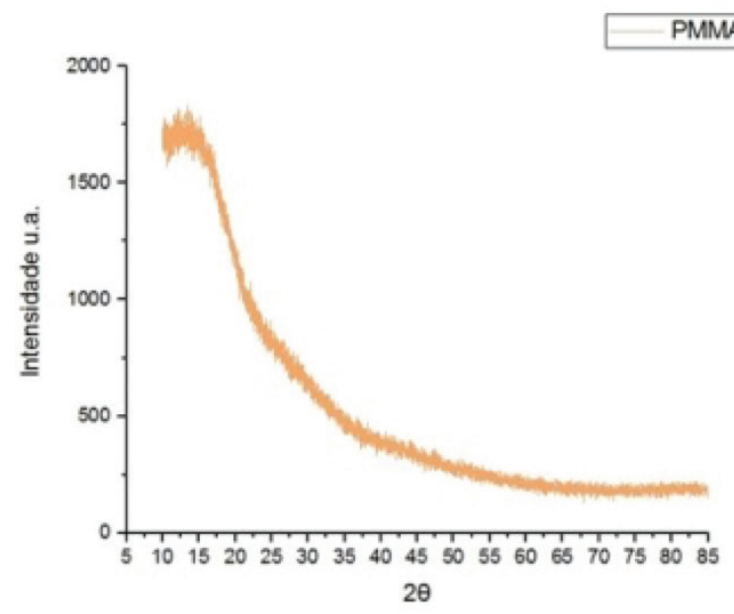

Figure 2 - Representative graphic of the DRX for PEI / PMMA fibers.

\section{Contact angle analysis}

For the analysis of the average contact angle, 3 samples were used, which obtained an average result of $116.79^{\circ}$. It is possible to observe that the obtained fiber has a hydrophobic character, characteristic of polymeric materials [15]. The data obtained can be seen in Table IV.
Table IV - Data obtained by analyzing the contact angle of 3 samples of PEI/PMMA fibers from parameter PP4

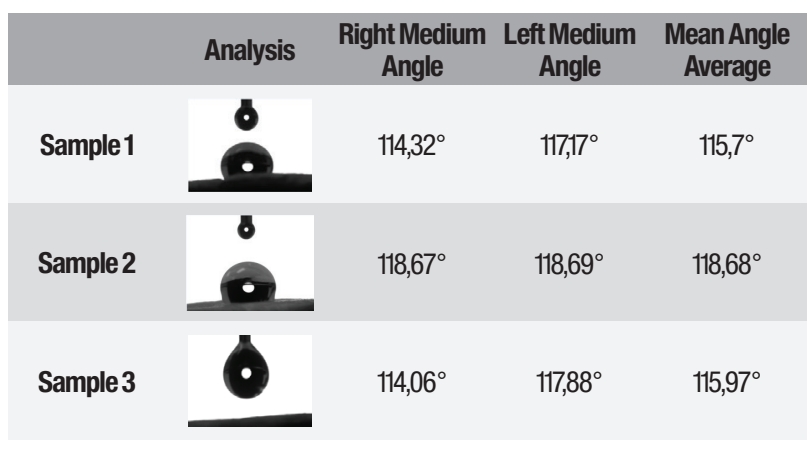

\section{DISCUSSION}

Composite resins are widely used in dentistry and are presented as an aesthetic material with low cost to be used in fixed partial dentures. Their disadvantage is their low fracture resistance when compared, for example, to fixed metal-ceramic partial prostheses, reducing their useful life [8].

The study in question was developed with the objective of fabricating hybrid ultrafine fibers, to reinforce for the composite resin in fixed partial prostheses, so that this reinforcement does not only act mechanically, but there is also a chemical interaction between the fiber and the resin.

For this, we chose to use Polymethylmethacrylate, which has good mechanical resistance, high transparency, elasticity and good adhesion [15], Polyetherimide (PEI) is an amorphous thermoplastic polymer with excellent properties that include: high resistance mechanical, thermal and chemical stability. Their properties are compared with metallic and ceramic materials for their elasticity, toughness, impact and abrasion resistance, good insulation and chemical resistance and exposure to time [11]. 
According to the literature, the electrospinning parameters influence the structural morphology of the fibers, their variation is important for the optimization of fiber production [16]. These parameters are: solution flow, the potential difference that generates the electromagnetic field, the distance from the tip of the needle to the collection apparatus and the diameter of the needle $[1,3]$, in addition to humidity, temperature and viscosity. For the electrospinning process of PEI and PMMA ultrafine fibers, the variation of the distance $(\mathrm{D}=8$ and $12 \mathrm{~cm})$ and voltage $(\mathrm{V}=$ 10, 13 and $15 \mathrm{kV}$ ) parameters was prioritized, which were chosen at random with the purpose of optimizing the production fibers and were kept fixed for the six distinct groups formed by the association of distance and voltage parameters, flow parameters ( $F=2 \mathrm{mLh}-1)$, needle diameter $(\varnothing=0.7 \mathrm{~mm} 2)$, temperature $\left(24.1^{\circ} \mathrm{C}\right)$, humidity $(36 \%)$ and viscosity.

There is no consensus in the literature on the influence of applied stresses on the diameter of electrospun fibers. Studies show that the electric field has no influence on the diameter of the fibers [10]. However, some authors have suggested that higher voltages can increase the electrostatic repulsive force in the charged jet, favoring the narrowing of the fiber diameter [17] . In this study it was not possible to establish a direct correlation between voltage and fiber diameter.

The formation of beads in the electrospinning process is considered as local defects of the fibers attributed to different causes, such as lower surface voltage, higher voltage, viscosity solution and polymer concentration [18-20], these defects or lack of continuity of the fibers are directly related to the tensile strength and should be avoided. In cases where the purpose is the application of fibers as a mechanical reinforcement of other materials, beads lead to the weakening of the fibers. In this case, the ideal would be the absence of beads.
In cases where the purpose is for the controlled delivery of drug from the fibers, the beads could be used as a drug reservoir, where the stored drug would be released slowly and continue to the tissue, thus benefiting the formation of beads. The present study fabricated a scaffold (mesh formed by electrospun ultrafine fibers in large quantities) with the presence of two polymers from a single solution, resulting in bulky, uniform fibers with no beads. The production of reliable blankets for possible scale production insertion in composite resin to assess its mechanical performance.

The ultrafine fibers were chemically characterized using the X-ray Diffraction test, which consists of a non-destructive analysis to characterize materials, provides structural information, phases and crystallinity [21]. The mesh analyzed showed a predominantly amorphous nature, characteristic of the PMMA polymer [22]. Energy dispersion X-ray spectroscopy confirmed the presence of the polymers in question.

Future studies, the incorporation of hybrid non-woven fibers in restorative materials, such as composite, acrylic and Bisacryl resin, may improve the fracture toughness increase their mechanical performance.

\section{CONCLUSION}

Based on the proposal of this study, it can be concluded:

The method employed was efficient for the production of hybrid ultrafine PEI / PMMA fibers for using as reinforcement material.

The variation of the electrospinning process parameters influenced the structural morphology of the electrospun fibers.

Of the samples studied, the parameter 13 $\mathrm{kV} / 12 \mathrm{~cm}$ sample were considered standard. This standardization is important for the optimization of fiber scale production. 


\section{REFERENCES}

1. Costa AK, da Silva LH, Saavedra GS, Paes TJ Jr, Borges AL. Flexural strength of four adhesive fixed dental prostheses of composite resin reinforced with glass fiber.J Adhes Dent. 2012Feb;14(1):47-50. doi: 10.3290/j.jad.a21847.PMID: 21734978.

2. Ellakwa AE, Shortall AC, Shehata MK, Marquis PM. Influence of bonding agent composition on flexural properties of an Ultra-High Molecular Weight Polyethylene Fiber-Reinforced Composite. Oper Dent. 2002 MarApr;27(2):184-91.PMID: 11931138.

3. Huang ZM, Zhang YZ, Kotaki M, RamakrishnaS. A review on polymer nanofibers by electrospinning and their applications in nanocomposites. Compos Sci Technol. 2003;63(15):2223-53. doi:10.1016/S02663538(03)00178-7

4. Sun W,Cai Q, LiP,Deng X, Wei Y, Xu M, Yang X. Post-draw PAN-PMMA nanofiber reinforced and toughened Bis-GMA dental restorative composite. Dent Mater. 2010 Sep;26(9):873-80. doi:10.1016/j.dental.2010.03.022. Epub 2010 Jun 26. PMID:20579722.

5. Wang W, Ciselli P,KuznetsovE, Peijs T,Barber AH. Effective reinforcement in carbon nanotube-polymer composites. Philos Trans A Math Phys Eng Sci. 2008 May 13;366(1870):1613-26. do:: 10.1098/rsta.2007.2175. PMID: 18192168.

6. Uyar T,Çökeliler D, Dołan M, Koçum IC, Karatay 0, Denkbaş EB. Electrospun nanofiber reinforcement of dental composites with electromagnetic alignment approach. Mater Sci Eng C. 2016;62:762-70. doi: 10.1016/j.msec.2016.02.001

7. VidottiHA. 0 papel da concentração de nanofibras e da composição da matriz resinosa nas propriedades flexurais de compósitos experimentais baseados em nanofibras 2015; (Tese Doutorado)-Faculdade de Odontologia de Bauru. Universidade de São Paulo):113p

8. Borges ALS, MünchowEA, de Oliveira Souza AC, Yoshida T, Vallittu PK, Bottino MC. Effect of random/aligned nylon-6/MWCNT fibers on dental resin composite reinforcement. J Mech Behav Biomed Mater. 2015 Aug;48:134-144. doi: 10.1016/j.jmbbm.2015.03.019. Epub 2015 Apr 1.PMID:25933169.

9. Xue J, Wu T,Dai Y,Xia Y.Electrospinning and electrospun nanofibers: Methods, materials, and applications. Chem Rev.2019;119(8):5298-415. doi: 10.1021/acs. chemrev.8b00593

10. Dzenis Y.Material science. Spinning continuous fibers for nanotechnology. Science. 2004 Jun 25;304(5679):1917-9. doi: 10.1126/science.1099074.PMID: 15218134.

11. Reneker DH, Yarin AL Electrospinning jets and polymer nanofibers. Polymer (Guildf).2008;10:2387-425. doi:10.1016/.jpolymer.2008.02.002

12. Johnson RO, Burhis HS. Polyetherimide: A new high-performance thermoplastic resin. J Polym Sci Polym Symp. 2007;70(1):129-43. doi:10.1002/ polc.5070700111
13. Liu G, Ding J, Qiao L, Guo A, Dymov BP, Gleeson JT, et al. Polystyreneblock-poly(2-cinnamoylethyl methacrylate) Nanofibers-Preparation, Characterization, and Liquid Crystalline Properties. Chem - A Eur J. 1999;5(9):2740-9. doi: 10.1002/(sici)1521-3765(19990903)5:9<2740:aidchem2740>3.0.c0;2-v

14. Mano EB. Polímeros Como Materiais de Engenharia.3a ed. São Paulo: 1991

15. Tian M, Gao Y, Liu Y,Liao Y, XuR, Hedin NE, Fong H. Bis-GMA/TEGDMA Dental Composites Reinforced with Electrospun Nylon 6 Nanocomposite Nanofibers Containing Highly Aligned Fibrillar Silicate Single Crystals. Polymer (Guildf). 2007 Apr 24;48(9):2720-2728. do::10.1016/.polymer.2007.03.032.PMID: 17940586; PMCID:PMC2031841.

16. Maturana LG, Pierucci A, Simões GF, Oliveira ALRde, Duek EA de R. Estudo das células Neuro2A sobre os biomateriais PCL e PLLA. Polímeros. 2014;24(6):733-9. doi: 10.1590/0104-1428.1555

17. Reiter J,Krejza 0, Sedlar̆́kováM. Electrochromic devices employing methacrylate-based polymer electrolytes. Sol Energy Mater Sol Cells. 2009;93(2):249-55. doi:10.1016/.jsolmat.2008.10.010

18. De Souza JR, Sato TP,Borges ALS. Scaffold architecture for dental biomaterials: influence of process parameters on the structural morphology of chitosan electrospun fibers. Brazilian DentSci. 2017;20(4):1000-5. doi:10.14295/ bds.2017.v20i4.1495

19. Yuan XY,Zhang YY,Dong C, Sheng J. Morphology of ultrafine polysulfone fibers prepared by electrospinning. Polym Int. 2004;53(11):1704-10. doi:10.1002/pi.1538

20. Chang $\mathrm{FC}$, Chan KK, Chang $\mathrm{CY}$. The effect of processing parameters on formation of lignosulfonate fibers produced using electrospinning technology. BioResources. 2016;11(2):4705-17. doi: 10.15376/biores.11.2.4705-4717

21. LuH, Lee YK, Oguri M, Powers JM. Properties of a Dental Resin Composite with a Spherical Inorganic Filler. Oper Dent. 2006;31(6):734-40. doi:10.2341/05-154

22. Miyoshi T, Toyohara K, Minematsu H.Preparation of ultrafine fibrous zein membranes via electrospinning. Polym Int. 2005;54(8):1187-90. doi:10.1002/ pi.1829

23. Bunaciu AA, Udriștioiu EG, Aboul-Enein HY.X-ray diffraction: instrumentation and applications. Crit Rev Anal Chem. 2015;45(4):289-99. doi: 10.1080/10408347.2014.949616.PMID:25831472.

24. Kaur K, Singh KJ, Anand V, Bhatia G, Kaur R, Kaur M, Nim L, Arora DS. Scaffolds of hydroxyl apatite nanoparticles disseminated in 1,6-disocyanatohexaneextended poly(1,4-butylene succinate)/poly(methyl methacrylate) for bone tissue engineering. Mater Sci Eng C Mater Biol Appl. 2017 Feb 1;71:780-790. doi: 10.1016/.msec.2016.10.055.Epub2016 0ct26. PMID:27987773.

\section{Elisa Camargo Kukulka} (Corresponding address)

Date submitted: 2020 ??? ??

Accept submission: 2021 ??? ?? 